\title{
Qualitative assessment of knowledge transfer regarding preterm birth in Malawi following the implementation of targeted health messages over 3 years
}

This article was published in the following Dove Medical Press journal:

International Journal of Women's Health

\author{
Kathleen M Antony ${ }^{1,2}$ \\ Judy Levison' \\ Melissa A Suter' \\ Susan Raine' \\ Grace Chiudzu ${ }^{3}$ \\ Henry Phiri ${ }^{3}$ \\ Joseph Sclafani ${ }^{1,3,4}$ \\ Michael Belfort ${ }^{1}$ \\ Peter Kazembe ${ }^{4}$ \\ Kjersti M Aagaard' \\ 'Department of Obstetrics and \\ Gynecology, Baylor College of \\ Medicine, Houston, TX, USA; \\ ${ }^{2}$ Department of Obstetrics and \\ Gynecology, Division of Maternal- \\ Fetal Medicine, University of \\ Wisconsin-Madison, Madison, WI, \\ USA; ${ }^{3}$ Department of Obstetrics and \\ Gynecology, Kamuzu Central Hospital, \\ Lilongwe, Malawi; ${ }^{4}$ Baylor College of \\ Medicine Children's Clinical Center of \\ Excellence, Kamuzu Central Hospital, \\ Lilongwe, Malawi
}

Correspondence: Kathleen M Antony

Department of Obstetrics and

Gynecology, Division of Maternal-Fetal

Medicine, University of Wisconsin-

Madison, 202 South Park Street, Madison,

WI 537I5-I599, USA

Tel +l 6084176099

Fax + I 6084174270

Email kantony@wisc.edu
Background: In 2012, we performed a needs assessment and gap analysis to qualitatively assess providers' and patients' knowledge and perceptions regarding preterm birth (PTB). During the study, we identified knowledge gaps surrounding methods to reduce the risk of occurrence of PTB and management options if preterm labor/birth occur. We targeted health messages toward these gaps. The objective of the present study was to assess the impact of our community health worker-based patient education program 3 years after it was implemented.

Methods: Fifteen focus groups including 70 participants were included in the study. The groups comprised either patients/patient couples or health providers. A minimum of two facilitators led each group using 22 a priori designed and standardized lead-in prompts for participants with four additional prompts for providers only. A single researcher recorded responses, and transcript notes were reviewed by the facilitators and interpreters immediately following each group discussion to ensure accuracy.

Results: The understanding of term vs preterm gestation was generally accurate. Every participant knew of women who had experienced PTB, and the general perception was that two to three women out of every ten had this experience. The majority of respondents thought that women should present to their local health clinic if they experience preterm contractions; few were aware of the use of antenatal steroids for promoting fetal lung maturity, but many acknowledged that the neonate may be able to receive life-sustaining treatment if born at a higher level of care facility. The majority of participants were aware that PTB could recur in subsequent pregnancies. All respondents were able to list ways that women could potentially reduce the risk of PTB.

Conclusion: After employing targeted health messages, the majority of participants expressed improved understanding of the definition of PTB, methods to prevent risk of PTB, and management options for preterm labor or PTB.

Keywords: preterm birth, qualitative research, global women's health, pregnancy, periodontal disease, prenatal education

\section{Background}

Worldwide, preterm birth (PTB) is the leading cause of childhood mortality, accounting for $15.4 \%$ of the 6.3 million children who died in their first 5 years of life in $2013.1,2$ Malawi has the highest rate of PTB in the world, with estimates ranging from $7.9 \%$ to $29.7 \% .^{2-8}$ Prematurity is a leading cause of newborn deaths: of the 2.6 million neonatal deaths that occur globally, prematurity is a direct cause of at least $27 \%$ and is a major risk 
factor in at least 50\%.$^{9-11}$ PTB and the resulting poor pregnancy outcome has been posited as a driver of high parity among women who seek to achieve their desired family size ${ }^{12}$ which increases maternal risks since women will risk being pregnant many times, and maternal mortality in low- and middle-income countries (LMIC) is high. ${ }^{13}$ Recognition of the high prevalence of PTB in sub-Saharan Africa, combined with the neonatal survival gap described above, has resulted in efforts aimed at achieving primary prevention of PTB and secondary interventions to care for preterm neonates. ${ }^{2,14,15}$ However, in our prior publication, we recognized that the success of these interventions depends upon the community wherein they occur; specifically, if at-risk women (or providers) have knowledge gaps, referrals and appropriate care may not occur. ${ }^{16}$ For instance, if patients are not aware that interventions are available, they may not seek care; if providers are unaware, they may not appropriately refer. ${ }^{16}$ Ultimately, the adoption and utilization of such interventions depends upon the community's perception of the problem and incorporation of the intervention into their belief system and standard practice. ${ }^{16}$

Therefore, in 2012, we performed needs assessment and gap analysis in four rural and urban communities surrounding Lilongwe, Malawi via focus groups as described in detail elsewhere. ${ }^{16}$ We specifically utilized qualitative research methods so that we could focus upon the community's beliefs and understanding surrounding PTB without imposing prespecified answers. ${ }^{16}$ Following this needs assessment, all members of the research team were debriefed to reflect upon and discuss the findings. Dissemination discussions were held with regional obstetricians, midwives, and medical and clinical officers and also community health workers (CHWs) to review the baseline level of understanding determined by the focus group assessments and to identify specific knowledge gaps to target for intervention. Terms, such as community health workers, are defined in Box 1. The overarching goal of these focus groups was to identify knowledge gaps and to then develop tailored educational materials and healthcare messages for CHWs and clinicians to assist with disseminating a public health message to pregnant women about PTB and oral health. These health messages, once created, were to be shared by the CHWs in their health messages, one-on-one care, and also with the broader community through speeches at antenatal clinics, songs, and with providers at continuing education workshops called "Open Days."

The specific knowledge gaps that we sought to address were: ${ }^{16}$

1. The definition of preterm vs term delivery with a focus on knowledge transfer to women about how the expected due date is determined and how far before that due date is considered to be "preterm" and "term."

2. Methods to reduce the risk of preterm labor (PTL) and PTB with a focus on seeking antenatal care so that known attributable risk factors could be identified, counseling could occur, and so treatment or further preventive measures could be offered and discussed.

3. Management plans and options for women who are experiencing preterm contractions, PTL, or PTB with specific knowledge transfer about the benefit of presenting for medical care, so that medications to help the baby can be given or so that the baby can be cared for if he or she is born.

In this follow-up study, we specifically sought to determine the current level of acquired understanding for the aforementioned knowledge gaps that we targeted in health messages delivered in a variety of culturally appropriate means (such as songs, role-playing, one-on-one conversations, and printed messages). We chose to assess knowledge transfer using the same methodology that we used in 2012 to assess knowledge gaps: focus groups. We also specifically queried about interventions and barriers to access to these interventions for women experiencing PTL or PTB or who have a history of PTB, the etiologies of PTB, and the perceived rate of PTB. Finally, we inquired about tobacco use and current oral healthcare practices because tobacco use and periodontal disease have been associated with PTB. ${ }^{7,17-67}$ A total of 15 focus groups were included, and both patient/ patient couples and healthcare providers were queried. These focus groups generally comprised different individuals than the attendees from 2012, thus we were able to assess the dissemination of our health messages into the community.

\section{Methods}

\section{Participants}

All studies were undertaken following Institutional Review Board (IRB) approval by the National Health Sciences Research Committee and the Malawi Ministry of Health (IRB00003905, FWA00005976). The work here adheres to the RATS guidelines (Relevance of study question, Appropriateness of qualitative method, Transparency of procedures, and Soundness of interpretative approach) for reporting the results of qualitative research. ${ }^{68,69}$ Baylor College of Medicine/Texas Children's Hospital has an established Clinical Center of Excellence in Lilongwe, Malawi in the campus of Kamuzu Central Hospital $(\mathrm{KCH}$, a government referral hospital) which is operated as part of the Baylor International Pediatrics Aids Initiative (Baylor, Malawi). 
Since 2011, Baylor College of Medicine's department of obstetrics and gynecology has collaborated with the Malawi Ministry of Health and the College of Medicine of Malawi to develop and implement a registrar program in obstetrics and gynecology at $\mathrm{KCH}$.

In 2012, we partnered with four community health centers (both rural and urban) located in and around Lilongwe with the goal of quantifying the rate of PTB at the centers and working with providers and the public to educate them about PTB. During that time, the initial qualitative assessment occurred in order to best tailor our messages. In May 2015, four additional sites were added and providers and CHWs attended our educational workshops, and the health messages were dispersed to these communities as well. The follow-up qualitative assessment of the impact of these messages was performed in September 2015.

An investigative team comprising one trained female clinician, a data recorder, and a minimum of two interpreters held fifteen focus groups of voluntary participants $(n=70)$ on consecutive days. Participants included patients (gravid and recently postpartum), patients' partners, nurse midwives, CHWs, nurses, matrons, clinical and medical officers, medical and dental assistants, and health surveillance assistants at the eight community health centers. The composition of each focus group is shown in Table 1. Two focus groups (or semistructured individual interviews in two instances) were conducted at each location except Lumbadzi where only one focus group was conducted. In one site, Mitundu, only one patient and one provider had participated, thus semistructured individual interviews occurred with the same lead in prompts utilized for the focus groups. Therefore, results were analyzed together. Inclusion criteria included being either a patient or a patient's partner (hereafter referred to as patients) or an obstetric provider, having English or Chichewa proficiency and being able to provide informed consent (Chichewa is the major language of Malawi and is spoken by over $57 \%$ of the population).

These groups were studied at eight community health centers located within or around the periphery of Lilongwe with the farthest site being $52 \mathrm{~km}$ from the center of town. All eight sites, in addition to providing antenatal care and family planning services, support a CHW network that provides prenatal and family planning education for women who are waiting for their antenatal visits. This program specifically delivers healthcare messages that align with the Malawi Ministry of Health programs and goals. All eight sites additionally provide maternity care, inclusive of vaginal deliveries with some sites additionally providing Cesarean delivery options.
All sites have the capacity to and are encouraged to appropriately refer to tertiary care hospitals, including $\mathrm{KCH}$ as per the Malawi Ministry of Health guidelines; education about indications for referrals was provided at the educational days described elsewhere. ${ }^{16}$

All potential participants were informed that participation was voluntary, and were provided with an overview of the discussion but not material nor questions. Volunteers were compensated for their travel expenses. In accordance with the IRB-approved protocol, verbal informed consent was obtained prior to the initiation of each focus group discussion. All the participants were informed that the study was approved by the National Health Sciences Research Committee, and a copy of the approval letter was made available. The investigators explained that the overarching study is supported by the March of Dimes and the Thrasher Foundation. All the participants were informed that our goal was to explore their beliefs and understandings and that there were no right or wrong answers and that all responses would be valued and respected. No identifying or demographic information was collected from the participants.

\section{Study design}

The working definition of focus groups were based upon the terminology as defined by Morgan. ${ }^{70}$ Morgan defines focus groups as "a research technique that collects data through group interaction on a topic determined by the researcher."70 Focus groups are specifically a research method, and the group discussion is the specific source of the data. ${ }^{70}$ Finally, these groups acknowledge the researcher's role in creating the group discussion for data collection purposes; for this study, discussion was prompted by semistructured, focused, lead-in prompts as described below. ${ }^{70}$ Separate focus groups comprising patients/partners and providers were held at seven of the eight community health centers and one focus group comprised of patients/partners was held at one of the eight community health centers because providers were not available to participate at that site; therefore, altogether 15 focus groups were completed. We used 22 predetermined, semistructured, focused, scripted, lead-in prompts to frame the discussions with further lead-in prompts scripted a priori if further facilitation or clarification was required. These questions are shown in Table 2. Healthcare providers were asked four additional questions, which are shown in Table S1. In order to maintain a non-threatening and receptive environment, participants were not required to answer every question.

Prior to the initiation of focus groups, all the questions were vetted by the clinician investigators. All the prompts 
Table I Composition of focus groups at each of the eight sites

\begin{tabular}{|c|c|c|c|c|c|}
\hline \multirow[t]{2}{*}{ Sites } & \multirow[t]{2}{*}{$\begin{array}{l}\text { Year added to } \\
\text { this educational } \\
\text { program }\end{array}$} & $\begin{array}{l}\text { Number of patients } \\
\text { and partners } \\
\text { interviewed }\end{array}$ & $\begin{array}{l}\text { Number of } \\
\text { providers } \\
\text { interviewed }\end{array}$ & Total interviewed & \multirow[t]{2}{*}{$\begin{array}{l}\text { Types of providers } \\
\text { interviewed }\end{array}$} \\
\hline & & $n=36$ & $n=34$ & $n=70$ & \\
\hline Area 18 & 2012 & 4 & 4 & 8 & $\begin{array}{l}\text { Midwives } \\
\text { CHWs } \\
\text { Nurses }\end{array}$ \\
\hline Area 25 & 2012 & 4 & 4 & 8 & $\begin{array}{l}\text { Midwives } \\
\mathrm{CHWs} \\
\text { Nurses } \\
\text { Health surveillance } \\
\text { assistants }\end{array}$ \\
\hline Chitedze & 2015 & 5 & 6 & 11 & $\begin{array}{l}\text { Midwives } \\
\mathrm{CHWs} \\
\text { Medical assistants } \\
\text { Health surveillance } \\
\text { assistants }\end{array}$ \\
\hline Kabudula & 2012 & 6 & 9 & 15 & $\begin{array}{l}\text { Midwives } \\
\text { Clinical officers } \\
\text { Nurses } \\
\text { Medical technicians } \\
\text { Sonographers } \\
\text { Dental technicians } \\
\text { Medical assistants } \\
\text { Field health workers }\end{array}$ \\
\hline Kawale & 2012 & 4 & 6 & 10 & $\begin{array}{l}\text { Midwives } \\
\text { CHWs } \\
\text { Dental officers } \\
\text { Clinical officers }^{\mathrm{a}}\end{array}$ \\
\hline Lumbadzi & 2015 & 6 & $0^{\mathrm{b}}$ & 6 & \\
\hline Mitunduc & 2015 & 1 & 1 & 2 & CHWs \\
\hline Nathenje & 2015 & 6 & 4 & 10 & $\begin{array}{l}\text { Midwives } \\
\text { CHWs } \\
\text { Clinical officers } \\
\text { Nurses }\end{array}$ \\
\hline
\end{tabular}

Notes: An independent researcher and the facilitators manually recorded the time, number of responses, and verbatim nature of the recorded notes. These tabulations were internally checked, and consensus was reached immediately following each session. Further clarification regarding language, statement, and contextual inference was achieved with the help of interpreters. Such clarification was sought either immediately after the interview or by the end of the same day as the interview occurred. Patients were either pregnant or recently postpartum, and partners were defined as the self-identified father of the index pregnancy. Patient participants had pregnancies complicated by HIV, history of pregnancy loss, preterm birth, miscarriage, hypertensive disorders, anemia, and malaria. Such information was not formally collected or reported due to confidentiality concerns, particularly in the setting of the low number of participants. However, this information may have been self-disclosed during the course of the group discussions. ${ }^{a}$ Clinical officers are similar to a community practice physician or advanced physician assistant, typically with 2 years of formalized training followed by 18-24 months of multidisciplinary internship. Clinical officers are well-versed in prevalent complications in obstetrics and gynecology and common interventions, including

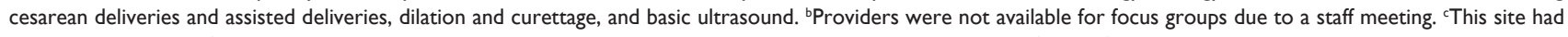
low attendance, therefore semi-structured individual interviews occurred with the same lead in prompts utilized for the focus groups.

Abbreviation: $\mathrm{CHW}$, community health worker.

were designed to qualitatively assess providers' and patients' knowledge and perceptions regarding PTB, oral health, or smoking. Each focus group lasted $\sim 90$ minutes, including introductions and informed consent. Questions were asked by the facilitator in English with translation into Chichewa by the research coordinator and $\mathrm{CHW}$; each confirmed each other's translations and provided a secondary means of clarification. Therefore, at least two interpreters were present to assure that accurate interpretation would occur and that responses would not be biased or misparaphrased as can occur with only one interpreter. Answers given in Chichewa were translated into English by the interpreter. One researcher recorded the responses in writing and audiotape, and these notes were reviewed by the facilitators and interpreters immediately following each session. A generated transcript was later checked for accuracy and bias. In total, four researchers were present at each focus group, including the research-facilitator, two interpreters, and the recorder, with roles as described above.

At the time of our prior investigation, we had been advised that having groups comprising both men and women 
Table 2 Lead-in prompts for focus group discussion

\begin{tabular}{|c|c|}
\hline Topic & Question \\
\hline \multicolumn{2}{|c|}{ General pregnancy questions } \\
\hline Gestation & $\begin{array}{l}\text { - What is the normal length of pregnancy? } \\
\text { - How is expected date of delivery determined? }\end{array}$ \\
\hline Prenatal and obstetric care & $\begin{array}{l}\text { - Why would women not come or come late for antenatal care appointments? } \\
\text { - Do you know of women who plan to deliver at home or in their village? } \\
\text { - Would it matter if the baby was being born too soon? } \\
\text { - On their due date? }\end{array}$ \\
\hline \multicolumn{2}{|l|}{ Preterm birth } \\
\hline Counseling & - What if a woman has pain a few months prior to her expected delivery date? \\
\hline Epidemiology & $\begin{array}{l}\text { - How common is preterm birth? } \\
\text { - Scripted prompt: "If you had ten women gathered who have had children, how many would have had a preterm } \\
\text { birth? One? Two? Three? Four? Five? Six?" } \\
\text { - What are causes of women delivering early, like at } 6 \text { or } 7 \text { months? } \\
\text { - At what gestational age can a baby survive? }\end{array}$ \\
\hline Recurrent preterm birth & $\begin{array}{l}\text { - Have you heard of recurrent preterm birth? } \\
\text { - If a woman has a history of preterm birth }(800 \mathrm{~g} \text { or I } \mathrm{kg} \text { or even } 2 \mathrm{~kg}) \text {, would she be referred antenatally? }\end{array}$ \\
\hline $\begin{array}{l}\text { Management of preterm } \\
\text { birth }\end{array}$ & $\begin{array}{l}\text {-Why would a woman not come to a health center when in preterm labor or with antenatal problems? } \\
\text { - What can be done at a health center if preterm delivery occurs or might occur? } \\
\text { - Have you ever heard of medicines that can be given to the mother to make the baby more ready if she delivers } \\
\text { early or that can prevent the recurrence of preterm labor? } \\
\text { - Have you heard about using antenatal steroids for fetal lung maturity? Shots to the mom for helping a baby } \\
\text { breathe better? What have you heard? Any potential harm? When can they be used? When can they not be used? } \\
\text { - Would women come in early if medications were available? }\end{array}$ \\
\hline Prevention of preterm birth & - Are there ways to prevent preterm birth? \\
\hline \multicolumn{2}{|l|}{ Smoking and tobacco } \\
\hline General information & $\begin{array}{l}\text { - Do people in Malawi smoke tobacco? Chew or gum tobacco? What are your thoughts on pregnant women } \\
\text { smoking or chewing or gumming tobacco? }\end{array}$ \\
\hline Risks of smoking or tobacco & - Are there potential risks or harm to chewing or smoking tobacco? \\
\hline \multicolumn{2}{|c|}{ Oral health and xylitol-containing gum } \\
\hline Chewing gum & $\begin{array}{l}\text { - Would you believe it if someone told you that chewing gum might help prevent preterm birth? } \\
\text { - Is gum acceptable? }\end{array}$ \\
\hline $\begin{array}{l}\text { Oral health and preterm } \\
\text { birth }\end{array}$ & - If we tell you that the same bacteria that can cause gum disease may cause preterm birth, would you believe it? \\
\hline General tooth care & - What is usual tooth care? \\
\hline
\end{tabular}

might lead to men dominating the conversation or that women may conversely choose to not participate if their husbands could not also be present. We demonstrated that the majority of responses to these questions were given by women, that there was no evidence of subversion of answers, and therefore that the gender of the respondent was not accounted for in the present study. ${ }^{16}$

\section{Data analysis}

All members of the research team including the interpreters were "debriefed" after each interview or discussion group to enhance and to confirm the findings.

Source data were triangulated both between and among focus groups and key informant interviews, and iterative data analysis was carried out employing a framework analytic approach. ${ }^{71}$ NVivo 11 software (QSR International, Burlington, MA, USA) was used as a secondary means of coding nodes and identifying themes. Due to the large number of study participants, each subject was not assigned a code number, but data were coded into nodes (nodes are an overarching content area) according to the lead-in prompts. Researchers then searched for themes. Themes are defined as an interpretive narrative which stems from or connects the nodes. ${ }^{16,72,73}$ The facilitators discussed their interpretation of both major and minor themes; major themes were defined as the most common theme brought up in discussion for a specific lead-in prompt and minor themes were the second (and sometimes third) most common. 
Finally, following each session, we provided standard information about PTB. We also answered any questions that arose, corrected misconceptions, and provided additional information if requested. This was performed after data analysis was complete. Corrections of misconceptions and provision of information are critical to our overarching aim of improving knowledge regarding PTB.

\section{Results}

Table 1 shows an overview of the discussion group participants by site, including the type of health providers who participated. Total time in direct volunteer subject interaction was 1,350 minutes. The order of interview group was varied by site and day of interview. The ratio of questions asked to answers given were tracked by data recorders. At all sites,
22 questions were asked for a total of 330 questions, and there were 511 responses for a ratio of 1.55 answers to one question. Answers did not vary by site or by year of entry into the educational program; therefore, answers from all sites were analyzed together.

Analyses of notes from all focus groups revealed major and minor themes which emerged from our discussions on PTB as summarized in Table 3.

\section{Pregnancy duration and how gestational age is assessed}

There were 30 responses to our lead-in prompt about the normal length of pregnancy: 18 patient responses and 12 provider responses. The normal length of pregnancy was most commonly described by patients as 9 completed

Table 3 Iterative responses by discussion group, highlighting emerged major and minor themes

\begin{tabular}{|c|c|c|}
\hline Topic discussed & $\begin{array}{l}\text { Patients/patient couples } \\
\text { Major themes } \\
\text { - Minor themes }\end{array}$ & $\begin{array}{l}\text { Healthcare providers } \\
\text { Major themes } \\
\text { - Minor themes }\end{array}$ \\
\hline \multicolumn{3}{|l|}{ Pregnancy/ANC } \\
\hline Length of a normal pregnancy & $\begin{array}{l}9 \text { finished months } \\
\text { - } 36 \text { or } 37 \text { weeks }\end{array}$ & $\begin{array}{l}40 \text { weeks } \\
\text { - } 9 \text { completed months }\end{array}$ \\
\hline How due date is known & $\begin{array}{l}\text { Counts from LMP } \\
\text { - [Ultrasound] }\end{array}$ & $\begin{array}{l}\text { History taking with LMP } \\
\text { - [Ultrasound] }\end{array}$ \\
\hline Barriers to ANC & $\begin{array}{l}\text { Ignorance } \\
\text { Afraid to come } \\
\text { - [Distance/transportation] } \\
\text { - [Too many visits/tired] }\end{array}$ & $\begin{array}{l}\text { [Culture/religion] } \\
\text { [Distance/transportation] } \\
\text { - Afraid of HIV testing } \\
\text { - Do not want to come to ANC }\end{array}$ \\
\hline $\begin{array}{l}\text { Whether women deliver at home and } \\
\text { when those women would go to the } \\
\text { hospital }\end{array}$ & $\begin{array}{l}\text { [Yes] } \\
\text { - Many come to the health center when they have pain } \\
\text { before the due date }\end{array}$ & [Yes, if preterm contractions] \\
\hline \multicolumn{3}{|l|}{ Preterm birth } \\
\hline Actions to take if preterm contractions & $\begin{array}{l}\text { She would come in } \\
\text { - She will find her way to the health center hoping for } \\
\text { care or for proper management } \\
\text { - [Goat fines] }\end{array}$ & $\begin{array}{l}\text { Now the women will come } \\
\text { - Many think of getting more help }\end{array}$ \\
\hline Frequency of preterm birth & Two or maybe three [out of ten] & Two or three of ten \\
\hline Causes of preterm birth & $\begin{array}{l}\text { [Infection] } \\
\text { - Malaria } \\
\text { - }[\text { Periodontal disease] } \\
\text { - }[\text { Short interpregnancy interval] } \\
\text { - Hard work }\end{array}$ & $\begin{array}{l}\text { [Infection] } \\
\text { - Malaria } \\
\text { - Anemia } \\
\text { - [Short interpregnancy interval] }\end{array}$ \\
\hline Earliest age a baby can survive & $\begin{array}{l}6 \text { or } 7 \text { months } \\
\text { - I kg } \\
\text { - } 1.5-2 \mathrm{~kg}\end{array}$ & $\begin{array}{l}28 \text { weeks } \\
\text { - We have heard of } 600 \text { or } 800 \mathrm{~g} \\
\text { - I-I.5 kg } \\
\text { - For sure above } 1.5-2 \mathrm{~kg}\end{array}$ \\
\hline Knowledge of recurrent PTB & $\begin{array}{l}{[\text { Yes] }} \\
\text { - Yes but not common }\end{array}$ & $\begin{array}{l}\text { - }[\text { Yes] } \\
\text { - Yes but it is not so common }\end{array}$ \\
\hline Referral for history of PTB & $\begin{array}{l}\text { Yes } \\
\text { - We do not know }\end{array}$ & Yes \\
\hline
\end{tabular}


Table 3 (Continued)

\begin{tabular}{|c|c|c|}
\hline Topic discussed & $\begin{array}{l}\text { Patients/patient couples } \\
\text { Major themes } \\
\text { - Minor themes }\end{array}$ & $\begin{array}{l}\text { Healthcare providers } \\
\text { Major themes } \\
\text { - Minor themes }\end{array}$ \\
\hline $\begin{array}{l}\text { Barriers to accessing a community } \\
\text { health center for preterm labor }\end{array}$ & $\begin{array}{l}\text { lgnorance } \\
\text { - Following advice is a problem } \\
\text { - For the reasons we have already shared against going } \\
\text { to antenatal care }\end{array}$ & $\begin{array}{l}\text { lgnorance } \\
\text { - For many of the same reasons as not } \\
\text { ANC }\end{array}$ \\
\hline Services available at health facilities & $\begin{array}{l}\text { Kangaroo care } \\
\text { - Be referred to } \mathrm{KCH} \text { or district } \\
\text { - Help for baby }\end{array}$ & $\begin{array}{l}\text { [Send to } \mathrm{KCH}] \\
\text { - }[\text { Kangaroo care] } \\
\text { - Help for baby }\end{array}$ \\
\hline Knowledge of antenatal steroids & $\begin{array}{l}\text { No } \\
\text { - We heard of the medicine for the lungs from the } \\
\text { health worker }\end{array}$ & Yes \\
\hline Would women come for medications? & Yes if they knew & Yes and they do \\
\hline $\begin{array}{l}\text { Knowledge of ways to prevent preterm } \\
\text { birth }\end{array}$ & $\begin{array}{l}\text { Antenatal care } \\
\text { - }[\text { Come to health center for PTL] } \\
\text { - }[\text { Avoiding causes] } \\
\text { - }[\text { Avoiding/treating malaria] }\end{array}$ & $\begin{array}{l}\text { Good history taking } \\
\text { - Contraception to keep the pregnancy } \\
\text { spaced } \\
\text { - }[\text { Avoiding causes }]\end{array}$ \\
\hline \multicolumn{3}{|l|}{ Smoking and tobacco } \\
\hline Pregnant women and tobacco & $\begin{array}{l}\text { Yes they do } \\
\text { - More women will gum when they are pregnant } \\
\text { - Some women stop when pregnant but sometimes } \\
\text { cannot }\end{array}$ & $\begin{array}{l}\text { Yes } \\
\text { - The pregnant women gum the tobacco }\end{array}$ \\
\hline Risks of tobacco & $\begin{array}{l}\text { [Preterm birth }] \\
\text { - }[\text { Maternal complications }] \\
\text { - [Fetal/newborn complications }]\end{array}$ & $\begin{array}{l}\text { [Preterm birth] } \\
\text { - [Fetal/newborn complications }]\end{array}$ \\
\hline \multicolumn{3}{|l|}{ Oral health and gum } \\
\hline Belief that gum could prevent PTB & $\begin{array}{l}\text { Yes } \\
\text { - [Request proof or explanation] }\end{array}$ & Yes, maybe \\
\hline Is gum acceptable? & Yes & Yes \\
\hline $\begin{array}{l}\text { Belief that the same bacteria } \\
\text { responsible for gum disease cause PTB }\end{array}$ & $\begin{array}{l}\text { Yes } \\
\text { - [Request proof or explanation] }\end{array}$ & $\begin{array}{l}\text { Yes } \\
\text { - [Request proof or explanation] }\end{array}$ \\
\hline Usual tooth care & $\begin{array}{l}\text { They use fingers and sand } \\
\text { - Colgate some use } \\
\text { - They use ashes }\end{array}$ & $\begin{array}{l}\text { Some use ash } \\
\text { [Brush and paste] }\end{array}$ \\
\hline
\end{tabular}

Note: All responses are direct quotations unless indicated with brackets.

Abbreviations: ANC, antenatal clinic; LMP, last menstrual period; PTB, preterm birth; PTL, preterm labor; KCH, Kamuzu Central Hospital.

months with the second and third most common responses being 36-37 weeks and 37-38 weeks, respectively, with a range of answers from 36 weeks up to 40 weeks. Over half of responses were given in terms of months rather than weeks. The following are representative of overall participant responses:

- "9 months to the end of the 9th month. But it depends on the date. If the period day is the middle of the month that the woman delivers more in the middle of the month."

The most frequent answer from providers was 40 weeks of pregnancy with the second most common answer being 9 completed months with a range of responses as low as 8 months and with none exceeding 40 weeks. Over half of all responses described gestational age in terms of weeks rather than months, and when the gestational age was described in months, it was typically given in terms of the provider's belief of what women think.

- "9 months. Often they do not know weeks but we would share with them that it is 38 to 42 weeks."

There were 33 responses to our lead-in prompt about how the expected date of delivery was determined: 15 patient responses and 18 provider responses. The most frequent answer from both patients and providers regarding how gestational age and the due date are assessed was from the last menstrual period with just less than half of respondents from each group referring to this method. The second and third most common answers for both the groups described the use of ultrasound to confirm the due date followed by the 
use of the month of the missed period rather than the exact date of the last period. Just less than $33 \%$ of patient respondents referenced ultrasound dating, whereas exactly $33 \%$ of providers discussed ultrasound dating. There was a general understanding that the due date may be changed based upon either clinical or sonographic assessments.

- "Sometimes we know days and can tell on our calendars. The calendars are on our phones or might be written."

- "Counting from period, but sometimes not to be believed."

- "Ultrasound. It is best to check early and not wait until late."

\section{Antenatal and obstetric care}

Our prior focus group work revealed a discrepancy in the perceived frequency of using traditional birth attendants, with patients perceiving that "half of women" delivered at home with traditional birth attendants and providers thinking that "zero" women engaged in this practice; ${ }^{16}$ therefore, we sought to query why women may not seek or obtain antenatal care or why they would choose to deliver at home or in their village rather than in a district hospital. There were 36 responses to our lead-in prompt about why women would not present for antenatal care visits: 16 patient responses and 20 provider responses. This prompt led to a myriad of replies, listing numerous reasons. While the most common answer was fear, other answers we received from patients included lack of transportation, too great a distance, too many visits required, lack of understanding of the policies, tired or bored of coming, negligence or lack of caring, no support from husband, religious beliefs, and being too shy. Some specific fears of presenting for antenatal care surrounded the concern that women would be tested for HIV as well as bad behavior of health workers. Sample patient responses included:

- "Some are afraid of being tested for HIV."

- "Most of the time if they don't come they are afraid."

- "Far distance, but many have a close clinic and will not go for ignorance."

- "Some women find it is a long journey. For some short journeys, they are too many."

- "Sometimes it is because of bad behavior of health workers ... The bad behavior some women might say is that they are not well received. Some women are late and then they are sent away."

Among healthcare providers, the two most frequent responses at five each were about distance or transportation concerns and religion or cultural beliefs. The third and fourth most frequent responses concerned women's fear of presenting for antenatal care with two such responses specifically referencing HIV testing concerns, and also that women just "don't want to come." Additional reasons included planned home births, thus women perceiving antenatal care as irrelevant, cost barriers, and not having clothes that were sufficiently fashionable to wear to the less rural clinic.

- "Some are distanced and challenged by transportation."

- "Some fear having to take drugs or blood that the religions do not allow."

There were 26 responses to our lead-in prompt about women planning to deliver in their village with a traditional birth attendant: 12 patient responses and 14 provider responses. Just less than half of all patients reported that they knew of women who planned to deliver in their village with a traditional birth attendant, but four patients clarified that these women would generally visit a healthcare center if they were experiencing PTL. One patient alluded to the fact that some traditional authorities, or chiefs, discourage home birth so strongly that women who purposely deliver at home are fined a goat.

- "Yes, some choose to do so [deliver at home]. These days it is not happening. If she delivers at home and it could have been prevented, then they will deliver a goat to the chief as punishment."

- "Yes, some women only have term at home but if preterm contractions will come in. Sometimes encouraged by traditional healers or chief to come in when premature." Providers were less likely to know of women planning to deliver in a village, but similarly discussed that women with such intentions frequently would come into the community health center for preterm contractions. Providers also emphasized that this message has been spread to women who have no antenatal care and that such women know that they should still come for preterm contractions, even if they did not get antenatal care.

- "Because services are far away some will go to traditional healers in the village. But sometimes they will work with the leaders to come in if not going well or is too soon or too small."

- "Now they come in if preterm birth. They have heard that they might be helped. Referral is done and proper management - now there is hope."

\section{Management of PTL}

There were 14 responses to our lead-in prompt about what to do if a woman has pains a few months prior to her expected delivery date: nine patient responses and five provider responses. The responses unanimously emphasized that a woman with pain before her due date would come to the 
community health center. One patient described, "She would still have to pay the goat fines so she would come when the premature pains come to avoid the fine. Also preventative cares to stop a premature baby." (Goat fines refer to the fines that some traditional authorities impose on women who purposely deliver at home; such women are often fined a goat.) Most others simply stated that the woman would come to the community health center or hospital and credited health messages to the village headman or chief in accomplishing this.

"Now the women will come. They feel pain months before the due date they will come to the facility or private clinic. [This is different from prior years] Things are changing. Now we deal with the village headman and they tell them to come. We work hand in hand with section leaders in the community. This helps the people in the village to come and tell women in early labor to come."

One participant noted that it can be difficult and that the transport time and duration of labor may play a role in whether the patient makes it to the hospital. "It becomes difficult. It depends on the time she is in labor. It also dependent on if the woman has an infection in her body that causes the preterm labor and if the baby is stillborn."

\section{Frequency and etiology of PTB}

There were 24 responses to our lead-in prompt about how common PTB is among women in Malawi: 12 patient responses and 12 provider responses. Both the sets of responses centered around an average of 2-3 women out of every 10 . Patients had a wider range of answers, ranging from 1 to 6 out of 10 with provider responses ranging from only 1-3.5 out of 10 .

- "When I have ten friends together I would find two or maybe three that would have had a preterm birth. Not more than three and not under two."

- "Two or three of ten, but the data may not be accurate. It might be more."

There were 91 responses to our lead-in prompt about the etiologies of PTB: 43 patient responses and 48 provider responses. Among patients, the three most common responses (at 6 each) referred to malaria, short interpregnancy interval, and periodontal diseases. These were followed by hard work (5), domestic violence (4), and anemia, stress, and infection in general (3 each). Other responses discussed hypertensive disorders, fistulas, other sexually transmitted diseases, and frequent miscarriages or abortions.

- "I was one of those women. I delivered at seven months and $1.6 \mathrm{~kg}$. She is now almost three years at two years and nine months. She went to Ethel Mutharika and was cared for there with proper management and stayed for two weeks. This pregnancy I waited to get pregnant. I would get to health center with pains. I tell other women to follow advice."

- "Poor oral health and swelling of the gums."

- "Spacing of babies. The womb is not ready and is tired."

- "Warm fluid in the uterus."

Providers also frequently cited malaria, short interpregnancy interval, and periodontal disease, but also had anemia, HIV, hypertensive disorders, and substance use (smoking and drinking) as common themes. Providers also discussed multi-fetal gestations, extremes of maternal age (both young and old), nutrition, and family history as causes of PTB.

- "Medical causes such as anemia or malaria and other issues in the woman's body, such as infection. Also sepsis."

- "Alcohol and smoking. These are bringing stresses to the woman's body."

- "Some have premature labor in the family. Some are sisters and some are mothers but they have it in the family."

There were 22 responses to our lead-in prompt about the gestational age at which a baby could survive; 11 from patients and 11 from providers. Patients most commonly responded that a baby could survive at 7 months, or somewhere in the range of $1-2 \mathrm{~kg}$. Providers most commonly responded that a baby could survive at 28 weeks, or a weight ranging from $<1 \mathrm{~kg}$ up to $2 \mathrm{~kg}$ with many noting that survival at $<1 \mathrm{~kg}$ is unlikely but possible at the central hospital. One provider also mentioned that the sex of the offspring influenced survival. "Sex matters - females more likely to survive."

\section{Recurrent PTB}

There were 19 responses to our lead-in prompt about recurrent PTB: nine from patients and ten from providers. Almost all patients knew women who had experienced recurrent PTBs; the majority (5) thought this was rare, but a significant minority (3) thought this was common.

- "Yes I have. I am believing it happens because I have seen it. I have a neighbor who delivered many times at 7 months."

- "Yes I knew a woman who that happened to three times."

Providers were all aware that women could experience recurrent PTB, but the majority of providers also thought this was rare (6). Providers also brought up that they usually see that such patients have a cerclage.

- "Yes, I had a friend. She only delivered premature and after 4 premature babies she had a suture and delivered term." 
- "Yes but then it is usually cervical insufficiency and a cerclage for proper management can be done."

There were 18 responses to our lead-in prompt about whether women would be referred to the central hospital prenatally if she had a history of PTB: ten from patients and eight from providers. The majority of both patient (7) and provider (7) responses indicated that women would be referred. Patients indicated that women may not come if they did not know that PTB was a problem, and providers indicated that the clinical histories obtained are sometimes incomplete and that a history of PTB may be missed. Providers also expressed concern that referring women to the central hospital can be a very long distance.

\section{Management of PTB}

There were ten responses to our lead-in prompt about reasons a woman would not come to a community health center if she were in PTL: six from patients and four from providers. Both cited ignorance as a major factor in women not coming to a community health center if she were in PTL. Patients also secondarily mentioned that even if women are told to go, they may not follow instructions. "One who is advised but still will not follow. Following advice is a problem." Both the groups also discussed that general barriers to antenatal care, such as distance and transportation, would also play a role in women not coming to a community health center for PTL.

There were 19 responses to our lead-in prompt about what would be done at a community health center if preterm delivery occurred or might occur: 12 from patients and 7 from providers. The majority of patients were aware that kangaroo care would be offered to the baby (7) and that women in labor could be referred from the community health center to the central hospital (6). (Kangaroo care is a method of holding the baby on the chest that maximizes skin to skin contact. Typically the baby is naked except for a diaper and a blanket [to cover the baby's back]. This method of holding a baby improves breastfeeding, temperature regulation, and bonding.) We did not query its acceptability in this present study, but other investigators have found it to be well received and generally acceptable, particularly after the benefits are explained..$^{7-80}$ Additional responses referenced the theme of help being available for the baby at these centers, including keeping the baby warm and giving oxygen. One respondent referenced corticosteroids for fetal maturity.

- "Put on oxygen for the baby. Put the baby in a warm place and kangaroo cares."

- "Referral or transfer to Ethel Mutharika. They then can get cares for the baby. We have heard of medicine to help the baby's lungs."
Providers similarly discussed that once at the community health center, women could be sent to the central hospital. They also cited kangaroo care and general help for the baby with one provider mentioning steroids.

- "If they deliver here at the community hospital we keep the baby warm and have kangaroo cares. We try for referral."

- "Referral to $\mathrm{KCH}$ [Kamuzu Central Hospital]. In the meantime, we examine the mother and give the corticosteroids if signs of labor progress. Say, dilation."

There were 14 responses to our lead-in prompt about whether the participants had heard of medications to give to the mother to make the baby more ready if she delivers early or that can prevent the recurrence of PTL: nine were from patients and five were from providers. The majority of patients had not heard of any such medications (7). Of respondents who had heard of such interventions, one was generally aware of interventions and one knew there were medications "for the lungs." All healthcare providers had heard of medications, specifically for fetal lung maturity, but the majority emphasized that these medications are not available to them. One healthcare provider additionally mentioned that nifedipine can be used to "stop the labor" and indicated that it is available.

We also had one lead-in prompt that specifically queried participants' knowledge about antenatal steroids, what they had heard about these medications, and whether there were any potential harmful effects. There were eleven responses: four from patients and seven from providers. Only one patient had heard of using steroids for fetal lung maturity, "but we have not heard of any bad." All providers who responded were aware of using antenatal steroids to promote fetal lung maturity, and one provider added "brain and stomach protection for the baby." Two providers mentioned that there can be risks to long-term steroid use, but denied concerns with the short course of antenatal corticosteroids. "There are problems with long term steroids and we do not give to the pregnant women. It puts them at risk for infection. But the antenatal steroids we have not heard of such risks and only of the good for the baby's lungs." When we asked about whether women would come into the community health centers early if medications were available, there were 12 responses: seven patients and five providers. Both the groups unanimously agreed that women would come to the community health centers if medications were available, but patients specified that women had to know about these medications being available (5) and also stipulated that the news about medication availability had to be true. 


\section{Prevention of PTB}

There were 31 responses to our lead-in prompt about whether there are ways to prevent PTB: 23 from patients and eight from providers. The most frequent responses from patients were about seeking antenatal care (5) and coming to the hospital for contractions (4) as ways to prevent PTB. Other common responses included preventing or treating malaria, and the national campaign to distribute bed nets to all pregnant women was mentioned. Patients also mentioned avoiding stress, hard labor, and treating infections ranging from periodontal disease to sexually transmitted infections.

- "There are ways to prevent preterm birth. Such ways are starting with ANC [antenatal care] and learning of the problems. Problems which are what led to preterm birth. Preventing from getting malaria and anemia with mosquito nets."

- "If you feel pain or bleed you find a way to the hospital."

- "Avoiding infections. Being certain the husband is treated for the infection."

Providers focused on the utility of a good clinical history and reviewing lab results in order to identify risks and also contraception and pregnancy spacing in addition to treating infectious diseases.

- "Yes, after looking at causes avoid what are the risks. This is the importance of the history taking and getting the antenatal labs."

- "Yes there are a lot of them. For example, if it is malaria we give appropriate treatment. Or anemia. Or family planning."

\section{Smoking}

There were 17 responses to our lead-in prompt about people in Malawi smoking or chewing tobacco and their thoughts on pregnant women smoking or chewing tobacco: ten from patients and seven from providers. All patients knew of women who used tobacco products during pregnancy. Respondents thought that chewing on tobacco was more common than smoking it, and a minority mentioned that women will try to stop smoking during pregnancy, but said it can be hard. Providers agreed that women were more likely to chew tobacco than smoke and also admitted that quitting can be a challenge and that women may switch to chewing (gumming) tobacco.

- "Yes too much. Some women smoke when not pregnant and do stop. But not all. Some women continue as they don't know to stop."

- "More common in men in rural area, and there many do. If women smoke they sometimes cannot stop because addicted. If they smoke, they might gum instead."
In response to our lead-in prompt about potential risks or harm to chewing or smoking tobacco, we had 19 responses: ten from patients and nine from providers. The majority of respondents listed PTB as a risk of tobacco with a significant minority of both patients and providers listing other maternal and fetal or neonatal risks ranging from maternal lung disease and asthma to babies being "born to small."

- "Yes it can cause preterm birth and for this we must not use."

- "Yes it is difficult. Because of the nicotine it is a concern for preterm birth."

- "They are at risk in pregnant women. Sometimes it will cause problems in the womb, and that can cause preterm births. It is the chemicals."

- "Preterm birth. She might delivery prematurely, and the development of the fetus might be affected. These effects might include the brain and growth deficits."

\section{Periodontal health and PTB}

In response to our lead-in prompt about whether respondents would believe that chewing gum could prevent PTB, there were 15 total responses: eight from patients and seven from providers. The majority (6) of patients believed this may be the case, and all providers (7) believed that this could be true. Patients wanted to be shown that it is true (3). "Yes we believe and want to be shown." We also asked about whether gum was acceptable for women to chew, and in response to this prompt, we had 15 responses: seven patients and eight providers. All participants agreed that gum was acceptable, although one patient thought that gum was "acceptable for some, but not for all." One provider also expressed that "some fear abortion but when we tell them reasons, they reassure (sic)."

In response to our lead-in prompt about whether they would believe that the same bacteria that cause gum disease may cause PTB, we had 13 responses: seven from patients and six from providers. The majority of patients (6) would believe this, but the majority (5) also wanted more explanation. One responder could not believe it yet.

- "Yes we would. The bacteria can cause swollen gums but which bacteria? We would like you to tell us."

- "If you tell us why we might believe. Right now we cannot."

All of the providers believed this, but the majority (5) also wanted more explanation.

- "Yes, we have come to hear of this. We look for more proof but it makes good sense."

- "Yes if you can explain pathology."

In response to our lead-in prompt asking participants to describe usual tooth care, we had 22 responses: 12 from 
patients and ten from providers. The majority of participants expressed their understanding that brushing with toothpaste is preferable, but qualified that they did not always have these items. Providers expressed that many patients think that these items are "a luxury." The most frequent other methods of tooth cleaning described by all participants involved a combination of fingers, brushes or sticks with sand, paste, ash, or salt. Sample patient responses include:

- "Many without Colgate [sic]. Without Colgate or toothbrush."

- "Brushing and toothpaste. But most do not have a toothbrush or the Colgate. They use ash. Some use fingers."

- "In the city they use Colgate. In the villages they use ash." Sample provider responses include:

- "Some think it is not a basic need and say it is a luxury."

- "Brushing and Colgate is what we share as best. But most use a finger or stick with sand or salt or ash."

\section{Questions for providers only}

We completed the providers' focus groups by asking what they would like to learn more about or whether they felt they had any knowledge gaps. The answers to these four questions overlapped significantly, and therefore, they are analyzed in aggregate. There were a total of 33 responses with the majority requesting additional education about PTB. Seven requested additional information about PTB management, four requested additional information about the relationship between periodontal disease, PTB with or without further explanation of the role of cariogenic bacteria, and the remaining questions about PTB surrounded prevention of recurrent PTB, the role of steroids, the appropriate mode of delivery for PTBs, and more information about causes of PTB. Finally, three respondents requested more information about periodontal disease and other health risks, and three respondents requested obstetric ultrasound training. Other requested education topics ranged from neonatal care, including kangaroo care and neonatal resuscitation, to contraception.

\section{Discussion}

We report the transfer of knowledge of patients and healthcare providers regarding the current level of community understanding about PTB 3 years after initial qualitative research was used to guide the generation of healthcare messages to eight community clinics in Lilongwe, Malawi. In our prior work, we identified knowledge gaps regarding how gestational age is determined, what women do if they experience preterm contractions, and what they think healthcare facilities can offer to manage PTL or PTB. In order to educate the medical providers, we hosted and enabled attendance for all obstetrical providers and staff at three separate continuing education workshops addressing these topics, called "Open Days." In order to educate the broader community, and specifically pregnant and reproductive aged women, health messages were developed in collaboration with our CHWs to distribute as health messages in the form of role modeling, group information sessions, one-on-one care, and songs that were presented and sung in the waiting room at the antenatal clinics. Many of these messages were reinforced with posters and signage. These presentations are held regularly (with every antenatal care clinic), and pregnant women (waiting at the antenatal clinic), their spouses/partners, and also women seeking care in the family planning clinic or gynecology clinic (which shares the same waiting area) all listen to and sing along with the health messages. This broad based approach allows for delivering messages in a culturally acceptable and utilized fashion, and thus this information is disseminated to the greater community in a culturally competent manner. The lyrics of one such song (translated into English) is available in Figure 1. Other messages emphasized early antenatal care, appropriate interpregnancy intervals, ${ }^{81-84}$ smoking cessation, ${ }^{85-87}$ nutrition, ${ }^{88,89}$ and the relationship between periodontal disease and PTB. ${ }^{7,17-56,61,64-67}$

In this follow-up study, we sought to determine the current level of understanding as knowledge transferred for the aforementioned knowledge gaps that we targeted in health messages. The normal length of gestation was previously generally accurate with patients describing pregnancy in terms of months and providers in weeks; our findings demonstrate that this discrepancy persists. This is the same discrepancy that we see in the United States wherein community members interpret a month as equivalent to 4 weeks which mathematically leads them to conclude that a pregnancy lasts 36 weeks (when they describe weeks). ${ }^{16}$ (This also results from dating a pregnancy from the missed period rather than the last period, which happens in both the United States and global non-medical communities.) The majority of respondents again perceived that the due date is determined by the last menstrual period, but now nearly a third of patient respondents expressed familiarity with the use of sonographic dating; previously no patients volunteered knowledge of ultrasound dating. ${ }^{16}$ One clinical officer specified that earlier ultrasound was the "best". There was also previously a perception that most patients knew the month but not the week of the LMP, but now patients specifically mentioned the week of the LMP or use calendars or phones. 


\section{Introduction (translated from Chichewa)}

My work is centered on safe motherhood initiatives with special attention on pre-mature children. Our program is called "serving life and death."

Today we will tackle a lot more issues, but before we go into the discussion, let's sing some songs. Let us just be flexible, do not panic. Seated at the back are our colleagues, doctors; we work together. Are we together?

So let us comfortably sing the songs, let's get started. Please back me up.

\section{Song}

Solo: As a mother you have made up your mind?

All: $\quad$ Sure

Solo: As a mother you have made up your mind?

All: Sure

You have made up your mind - sure

You have pushed your child to the wall

You are busy having sex with your husband - sure

Before engaging yourself in family planning services - sure

Mother eeehhh

Eeeeehhhh

Mother eeehheee

Wazawazawaza

Solo: You have given yourself tough time

All: You have given yourself tough time

Solo: At your back

All: You are carrying a child

Solo: In front

All: You are pregnant

Solo: At the side

All: You are carrying a child

Solo: On your shoulders

All: You are carrying a child

Solo: On your head

All: $\quad$ You are carrying a basket - this is self-created poverty You have given yourself tough time

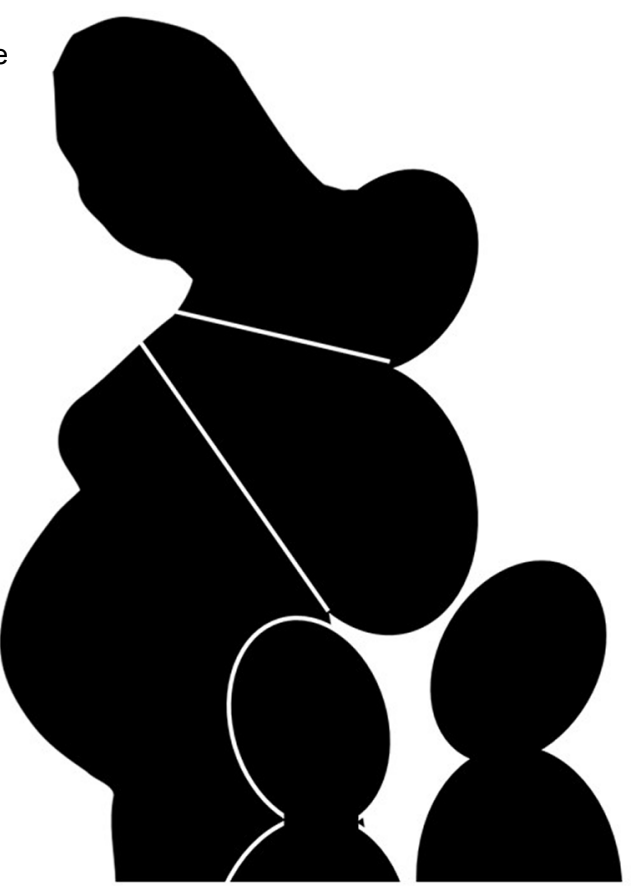

There is a complaint being raised in this song that it is not on that you should push your child aside and begin have sex with your husband before engaging in family planning services.

Will this child be happy?

All: $\quad$ No

\section{Discussion}

In order to prevent a preterm birth in your next pregnancy, go to a health center to get a family planning method so you do not get pregnant soon after a birth. When women wait at least 2 years after a baby is born, it lessens the chance of a preterm birth.

If you have had a prior preterm birth, you need to tell the clinician and you may be referred to the high-risk obstetrics clinic at Kamuzu Central Hospital $(\mathrm{KCH})$, also called Ethel Mutharika. You will learn about other risks in our next song.

Figure I This is an example of one of the songs used to transfer information about preventing a short interpregnancy interval.

Notes: The lyrics shown here have been translated from Chichewa into English and are shown verbatim as translated. In Chichewa, this song is set to a locally familiar tune. This and other songs (not included here) were presented and sung in the waiting room at the antenatal clinics.

Identified risk factors for PTB remained relatively consistent with infections listed as a major theme. While the etiology of PTB is multifactorial, its association with infection and inflammation, particularly genitourinary tract infection, has long been established. ${ }^{90-105}$ Both patients and providers also now identify periodontal disease as a risk factor for PTB. As we previously found, all participants agreed that women with preterm contractions would go to 
the community health center. ${ }^{16}$ However, barriers remain. Both providers and patients cited ignorance as a major reason that women would not go to a community health center and also discussed that distance and transportation may play a role. Patients were aware that by presenting to a community health center that "kangaroo care" could be offered and that transfer to the central hospital may also occur. They were also able to list several specific interventions for the baby, including antenatal corticosteroids, which were not previously mentioned. ${ }^{16}$ No respondents had concerns related to steroid safety at the doses used during pregnancy, despite the publication of a cluster randomized trial during the study interval. ${ }^{106}$ Knowledge of primary prevention of PTB focused upon preventing, mediating, or mitigating risk factors: treating (or not getting) infections, such as malaria or genital tract infections, treating or preventing periodontal disease, use of contraception to decrease short interpregnancy intervals, and avoiding domestic violence. No patients or providers discussed progesterone use, and upon inquiry it was not available. Our prior work demonstrated that it would be acceptable to use either formulation of progesterone in this community, including vaginal; during that time, many thought that vaginal progesterone would be preferable to patients because it would preclude the need to present to the community health center every week. ${ }^{16}$ In sum, patients demonstrated improved knowledge of interventions, such as kangaroo care and corticosteroids for fetal lung maturity.

Definitions of viability remained broad, which may reflect different experiences and practice of providers in the health centers. Patients generally cited 6-7 months as the threshold of viability, which is similar to our prior findings and in accordance with both the Ministry of Health advisement and regional practice patterns. ${ }^{16}$ When answers were given in terms of weights, patients listed a range from 1 to $2 \mathrm{~kg}$, which largely corresponds to this gestational age range, particularly if the whole 4-week range of any month is considered. In addition, the gestational age range and weight range of viability do depend upon the site of delivery and may explain some of the variances in response. ${ }^{107,108}$ Providers more consistently listed 28 weeks as the cutoff for viability with a corresponding weight range of $1-1.5 \mathrm{~kg}$ (average at 28 weeks is $\sim 1,210 \mathrm{~g}$ ). However, they also listed lower weight ranges for viability, as low as $500 \mathrm{~g}$, but they emphasized that this is rare. Taken together, the knowledge transfer was both reproducible and accurate, suggesting strong concordance between the aims to reduce knowledge gaps and the approaches undertaken to do so.

Regarding barriers to care, most of the patients referenced ignorance or fear as reasons that women do not seek care, whereas providers discussed distance/transportation issues and religious or cultural barriers to care. These barriers were similar to barriers identified by other investigators, with literacy, distance, and husbands often cited as predictors of birthing in a healthcare facility. ${ }^{109-115}$ Most of the patients knew women who had babies with the traditional birth attendants, but mentioned that these women would come to the health centers if they were in PTL. Participants also mentioned that the heads of villages, or chiefs, have been disseminating health messages about the importance of laboring at community health centers and have created a fine (a goat) which they impose upon women who purposely deliver at home. The uptake of the message to present to a community health center for signs of PTL was high; this is likely the result of the priority placed on this message by our educational program and also the Malawi Ministry of Health. Some patients also mentioned concerns about treatment by the health center staff. This is consistent with the findings of Kumbani who found that female patients in Malawi wanted to be well received and treated with kindness and respect and that this was valued over the quality of care they received. ${ }^{116}$ Regarding the frequency of PTB, patients had a wider range of answers about the frequency of PTB than providers, but this is likely related to personal experience or the experiences of their family and friends, whereas providers have a greater awareness of national data. Overall, the estimated frequency of PTB was $20 \%-30 \%$, which is similar to published estimates $(7.9 \%-29.7 \%)$. $^{2-8}$

We also sought to assess acceptance of a potential intervention to address one of the risk factors for PTB: periodontal disease. Prior studies and meta-analysis are classified on whether treating periodontal disease improves perinatal outcomes ${ }^{22,26,33,67,117-124}$ or not. ${ }^{125-134}$ Because many LMICs have a shortage of qualified dental providers to perform invasive interventions, ${ }^{135-137}$ a practical, easy to distribute, simple to use dental intervention which did not require clean water was sought. Xylitol is a sugar alcohol used in chewing gum, lozenges, and candies which the oral microflora cannot metabolize. ${ }^{138}$ It has been shown to decrease gingivitis scores, dental caries, the decayed, missing, filled surfaces (DMFS) score, and dental plaque scores. ${ }^{139-152}$ Almost all participants thought that gum was acceptable to use, and the majority were willing to believe that it could help decrease PTB if an explanation of the mechanism were provided. Participants also emphasized that most people were now aware of the best way to care for their teeth (toothbrush and toothpaste) but that it could be unaffordable and many used more traditional methods such as ash, sand, or salt rubbed on using fingers or a stick. It is of interest to note that, as 
we previously observed, both patients and providers largely sought a scientific and biologic plausibility for their illness or disease. ${ }^{16}$ We failed to observe a consistent belief that PTB was seen as "punishment" or blamed on the mother. Rather, we observed a consistent message of biologic function and dysfunction with an implied or stated belief that scientificbased therapeutics would offer eventual cure.

Given the biologic explanatory model as a basis of PTB disease, it is not surprising that when we asked about whether pregnant women use tobacco in Malawi, participants indicated that women who use tobacco try to stop, but that some switch from smoking to chewing. Overall, the consensus was that chewing tobacco was more common than smoking for pregnant women, and participants emphasized that quitting tobacco use is challenging. They further acknowledged that blame was not to be placed on the pregnant woman and that with education and efficacious management, she would want to quit if she thought it would benefit her baby or her family.

The responses to the providers-only questions were used to generate the curriculum for the third educational workshop ("Open Day"), wherein we presented didactics on PTB, but also a didactic lecture on the use of ultrasound for pregnancy dating and general assessment and also held a hands-on ultrasound workshop so that providers could practice their measurements and gain confidence in this skill.

Strengths of our study include the inclusion of patients and patient couples in addition to healthcare providers, interviewing participants at a familiar setting (their local clinic) and interviewing them in their native language. Reponses frequently included multiple themes, indicating that participants felt free to express themselves, and several answers identified complex concepts. The use of multiple bilingual interpreters ensured the accuracy of interpreted responses.

Limitations to our study include recruitment of patients and patient couples from their community health center, which may have preselected for a more educated group of participants. In particular, these participants likely heard the prepared health messages and songs during their antenatal care, so their understanding may not reflect the overall understanding of the community. However, it does demonstrate the uptake of the received messages. The groups comprised male and female participants, which could theoretically impact women's comfort in discussing pregnancy-related topics and is another potential limitation. However, our prior study indicated that the majority of responses were from females, indicating their comfort discussing these topics in a mixed group. ${ }^{16}$ Despite inviting participation and compensating travel expenses, some focus groups were also small. Finally, we did not directly assess exposure to the intervention nor did we assess which element or modality of the intervention participants were exposed to. It would have been valuable to know whether participants were exposed directly to the new information from their provider, speeches or songs in the antenatal clinic waiting rooms, or interpersonally through other individuals in their community. Having this information would best help us assess which elements of the intervention were the most effective and also the degree to which information had penetrated into the community.

\section{Conclusion}

In 2012 we identified knowledge gaps surrounding PTB. On the basis of these gaps, we identified three specific knowledge areas to target, and we developed health messages to address these. We first held three separate one-day workshops for 50-60 health workers from eight community health centers and mid-referral district hospitals. The goal of these workshops (called "Open Days") was to educate providers about the definitions of preterm and term birth, the best methods to determine gestational age, educate about the use of biometric ultrasound to determine the gestational age and due date, and also to educate about the causes of PTB and interventions that are available to prevent it, before pregnancy, during pregnancy, at the time of PTL, and interventions that are available for preterm babies. As noted above, we also hosted a hands-on ultrasound workshop to allow providers to practice biometric and general obstetric ultrasound skills. We surveyed Open Day participants at the start of the activity and after its completion using a quiz querying understanding of these topics. Following the first Open Day, the percentage of participants scoring above $80 \%$ on the assessment more than doubled (pretest vs posttest), and following the second Open Day, the percentage of participants scoring above $80 \%$ increased 16-fold (pretest vs posttest). In order to educate patients, together with the CHWs, we developed health messages that were relayed as speeches and also songs that were performed in the antenatal clinic waiting rooms.

Following the implementation of these health messages, participants are now able to list more causes of PTB, including several that are specifically mentioned in the health messages, such as periodontal disease and pregnancy spacing. They also sought further understanding of the biologic explanation for PTB and the rationale for the relationship between the risk factors and PTB. Participants are also able to list reasons for presenting to a community health center for preterm contractions. In addition, several CHWs have been reaching out to smaller villages and the village chiefs to emphasize our messages, such as the importance 


\section{Box I Vocabulary}

\begin{tabular}{|l|l|}
\hline Community health worker & $\begin{array}{l}\text { Individuals without formal health training, typically hired for a specific project or by community health centers or } \\
\text { (more commonly) by a nongovernmental organization (NGO). Their role is to educate patients and community } \\
\text { members through prepared speeches and songs. They also serve as a liaison with the community leaders to further } \\
\text { promote health messages }\end{array}$ \\
\hline $\begin{array}{l}\text { Primary health center/ } \\
\text { community health centers }\end{array}$ & $\begin{array}{l}\text { Often rural. Comprised of outpatient units (including antenatal clinics), holding beds, maternity units, antenatal units, } \\
\text { postnatal beds, and holding wards }\end{array}$ \\
\hline $\begin{array}{l}\text { Central hospital/tertiary } \\
\text { hospital }\end{array}$ & $\begin{array}{l}\text { Outpatient units (including antenatal clinics), holding beds, maternity units, antenatal units, postnatal beds, holding } \\
\text { wards, X-ray, imaging, ambulance, operating theater, laboratory, engineering department, specialized services }\end{array}$ \\
\hline Kangaroo care & Kangaroo care is a method of holding the baby on the chest that maximizes skin to skin contact ${ }^{74}$ \\
\hline
\end{tabular}

of antenatal care and presenting to the clinic for preterm contractions, and (outside of our sphere of influence) the chiefs are now encouraging pregnant women to present for antenatal care and discouraging planned deliveries at home. In sum, knowledge transfer was good; particularly for messages that targeted an action or available intervention. For example, the uptake of health messages related to presenting to a community health center for symptoms of PTL was high, as was the uptake of messages related to the availability of kangaroo care and corticosteroids at central hospitals.

In summary, using qualitative research methods in 2012, we were able to identify baseline gaps. Using this knowledge, we developed a curriculum for both providers and patient education. Based upon the responses, patients and providers are able to list more risk factors for PTB, including those included in health messages. They are also able to list more benefits of presenting to the community health centers for PTL, including that doing so allows the administration of antenatal steroids and possible transfer to a center with facilities capable of caring for a preterm baby. Finally, they seek a biologic explanation for PTB, which suggests that trials investigating interventions to prevent PTB would be well received. Future efforts focused upon improving access to additional primary preventive efforts, such as progesterone, or secondary preventive efforts, such as corticosteroids, are needed. Until then, continued efforts will target improving the rates of sonographic dating and preventing other risk factors, such as infections, including periodontal disease, and short interpregnancy intervals.

\section{Data sharing statement}

The data used during the current study are available from the corresponding author on reasonable request.

\section{Acknowledgments}

We would like to acknowledge Debora Nanthuru and Bertha Banda for their excellent leadership, guidance, and language and cultural skills as the research project managers for this project in Lilongwe, Malawi. We would like to also acknowledge Rose Chirwa, Mary Nyondo, Ellina Marko, Andrew Chigayo, Hanna Mkwate, Rabecca Kabati, Saukani Petro, and Kondwani Nkhwazi, who are community health workers in Malawi, for their subject matter expertise and for coordinating the focus group sessions. We would also like to acknowledge Dr Susan Ramin for her guidance and oversight of this project, her critical review of the manuscript, and for her role building and maintaining Baylor College of Medicine's clinical and academic partnership with Kamuzu Central Hospital and the surrounding clinics in Lilongwe, Malawi. This work is supported by the March of Dimes (S Raine and KM Aagaard), Thrasher Foundation (KM Aagaard), and USAID/Bill \& Melinda Gates Foundation Saving Lives at Birth Grand Challenges Grant: AID-OAA-G-11-00062 (KM Aagaard). Dental findings were presented in a poster at the Society of Maternal-Fetal Medicine's 36th Annual Meeting - The Pregnancy Meeting TM, Atlanta, GA, USA, February 1-6, 2016, Abstract Number 549.

\section{Author contributions}

All authors contributed to data analysis, drafting and revising the article, gave final approval of the version to be published, and agree to be accountable for all aspects of the work.

\section{Disclosure}

The authors report no conflicts of interest in this work.

\section{References}

1. Liu L, Johnson H, Cousens S. Global, regional, and national causes of child mortality in 2000-2010: an updated systematic analysis. Lancet. 2015;385(9966):430-440.

2. World Health Organization. Born Too Soon: The Global Action Report on Preterm Birth. Geneva: World Health Organization; 2012. Available from: http://apps.who.int/iris/bitstream/10665/44864/1/9789241503433_ eng.pdf. Accessed December 16, 2016.

3. Blencowe H, Cousens S, Oestergaard MZ, et al. National, regional, and worldwide estimates of preterm birth rates in the year 2010 with time trends since 1990 for selected countries: a systematic analysis and implications. The Lancet. 2012;379(9832):2162-2172. 
4. van den Broek N, Ntonya C, Kayira E, White S, Neilson JP. Preterm birth in rural Malawi: high incidence in ultrasound-dated population. Hum Reprod. 2005;20(11):3235-3237.

5. van den Broek NR, White SA, Goodall M, et al. The apple study: a randomized, community-based, placebo-controlled trial of azithromycin for the prevention of preterm birth, with meta-analysis. PLoS Med. 2009;6(12):e1000191-e1000198.

6. Kulmala T, Vaahtera M, Ndekha M, et al. The importance of preterm births for peri- and neonatal mortality in rural Malawi. Paediatr Perinat Epidemiol. 2000;14(3):219-226.

7. Harjunmaa U, Järnstedt J, Alho L, et al. Association between maternal dental periapical infections and pregnancy outcomes: results from a crosssectional study in Malawi. Trop Med Int Health . 2015;20(11):1549-1558.

8. van den Broek NR, Jean-Baptiste R, Neilson JP. Factors associated with preterm, early preterm and late preterm birth in Malawi. PLoS One. 2014;9(3):e90128.

9. Lawn JE, Gravett MG, Nunes TM, Rubens CE, Stanton C, GAPPS Review Group. Global report on preterm birth and stillbirth (1 of 7) definitions, description of the burden and opportunities to improve data BMC Pregnancy Childbirth. 2010;10(Suppl 1):S1.

10. Lawn JE, Cousens S, Zupan J. Neonatal Survival 14 million neonatal deaths: When? Where? Why? Lancet. 2005:9-18.

11. Hug L, Sharrow D, Sun Y. United Nations Inter-Agency Group for Child Mortality Estimation (UN IGME): Levels and Trends in Child Mortality Report 2017. The United Nations Children's Fund, ed. New York, NY: United Nations Children's Fund 3 UN Plaza, 10017 USA World; 2017. Available from: http://www.childmortality.org/files_v21/download/ IGME report 2017 child mortality final.pdf. Accessed November 9, 2018.

12. Tolhurst R, Theobald S, Kayira E, et al. 'I don't want all my babies to go to the grave': perceptions of preterm birth in Southern Malawi. Midwifery. 2008;24(1):83-98.

13. World Heath Organization. [homepage on the Internet]. Maternal mortality. WHO; 2015. Available from: http://www.who.int/mediacentre/ factsheets/ fs348/en/. Published 2015. Accessed April 26, 2016.

14. Barros FC, Bhutta Z, Batra M, et al. Global report on preterm birth and stillbirth (3 of 7): evidence for effectiveness of interventions. BMC Pregnancy Childbirth. 2010;10(Suppl 1):S3-S36.

15. Iams JD, Romero R, Culhane JF, Goldenberg RL. Primary, secondary, and tertiary interventions to reduce the morbidity and mortality of preterm birth. The Lancet. 2008;371(9607):164-175.

16. Levison J, Nanthuru D, Chiudzu G, et al. Qualitative assessment of attitudes and knowledge on preterm birth in Malawi and within country framework of care. BMC Pregnancy Childbirth. 2014;14(1):123.

17. Galloway CE. Focal infection. Am J Surgery. 1931;14(3):643-645.

18. Khader Y, Al-Shishani L, Obeidat B, et al. Maternal periodontal status and preterm low birth weight delivery: a case-control study. Arch Gynecol Obstet. 2009;279(2):165-169.

19. Al Habashneh R, Khader YS, Jabali OA, Alchalabi H. Prediction of preterm and low birth weight delivery by maternal periodontal parameters: receiver operating characteristic (ROC) curve analysis. Matern Child Health J. 2013;17(2):299-306.

20. Dörtbudak O, Eberhardt R, Ulm M, Persson GR. Periodontitis, a marker of risk in pregnancy for preterm birth. J Clin Periodontol. 2005;32(1): 45-52.

21. Goepfert AR, Jeffcoat MK, Andrews WW, et al. Periodontal disease and upper genital tract inflammation in early spontaneous preterm birth. Obstet Gynecol. 2004;104(4):777-783.

22. Jeffcoat MK, Hauth JC, Geurs NC, et al. Periodontal disease and preterm birth: results of a pilot intervention study. J Periodontol. 2003;74(8):1214-1218.

23. Khader YS, Ta'ani Q. Periodontal diseases and the risk of preterm birth and low birth weight: a meta-analysis. J Periodontol. 2005;76(2): 161-165.

24. Konopka T, Rutkowska M, Hirnle L, Kopec W, Karolewska E. The secretion of prostaglandin E2 and interleukin 1-beta in women with periodontal diseases and preterm low-birth-weight. Bull Gr Int Rech Sci Stomatol Odontol. 2003;45(1):18-28.
25. López NJ, Smith PC, Gutierrez J. Higher risk of preterm birth and low birth weight in women with periodontal disease. J Dent Res. 2002; 81(1):58-63.

26. López NJ, Smith PC, Gutierrez J. Periodontal therapy may reduce the risk of preterm low birth weight in women with periodontal disease: a randomized controlled trial. J Periodontol. 2002;73(8):911-924.

27. Mokeem S, Molla G, Al-Jewair T. The prevalence and relationship between periodontal disease and pre-term low birth weight infants at King Khalid university hospital in Riyadh, Saudi Arabia. J Contemp Dent Pr. 2004;5(2):40-56.

28. Bošnjak A, Relja T, Vucićević-Boras V, Plasaj H, Plančak D. Pre-term delivery and periodontal disease: a case-control study from Croatia. J Clin Periodontol. 2006;33(10):710-716.

29. Offenbacher S, Boggess KA, Murtha AP, et al. Progressive periodontal disease and risk of very preterm delivery. Obstet Gynecol. 2006;107(1): 29-36.

30. Oittinen J, Kurki T, Kekki M, et al. Periodontal disease and bacterial vaginosis increase the risk for adverse pregnancy outcome. Infect Dis Obstet Gynecol. 2005;13(4):213-216.

31. Radnai M, Gorzó I, Nagy E, Urbán E, Novák T, Pál A. A possible association between preterm birth and early periodontitis. A pilot study. J Clin Periodontol. 2004;31(9):736-741.

32. Romero BC, Chiquito CS, Elejalde LE, Bernardoni CB. Relationship between periodontal disease in pregnant women and the nutritional condition of their newborns. J Periodontol. 2002;73(10):1177-1183.

33. Sadatmansouri S, Sedighpoor N, Aghaloo M. Effects of periodontal treatment phase I on birth term and birth weight. J Indian Soc Pedod Prev Dent. 2006;24(1):23-26.

34. Xiong X, Buekens P, Fraser WD, Beck J, Offenbacher S. Periodontal disease and adverse pregnancy outcomes: a systematic review. BJOG Int J Obstet Gynaecol. 2006;113(2):135-143.

35. Alchalabi HA, Al Habashneh R, Jabali OA, Khader YS. Association between periodontal disease and adverse pregnancy outcomes in a cohort of pregnant women in Jordan. Clin Exp Obstet Gynecol. 2013; 40(3):399-402.

36. Walia M, Saini N. Relationship between periodontal diseases and preterm birth: recent epidemiological and biological data. Int J Appl Basic Med Res. 2015;5(1):2-6.

37. Offenbacher S, Katz V, Fertik G, et al. Periodontal infection as a possible risk factor for preterm low birth weight. J Periodontol. 1996;67(10s): 1103-1113.

38. Alves RT, Ribeiro RA. Relationship between maternal periodontal disease and birth of preterm low weight babies. Braz Oral Res. 2006; 20(4):318-323.

39. Jarjoura K, Devine PC, Perez-Delboy A, Herrera-Abreu M, D’Alton M, Papapanou PN. Markers of periodontal infection and preterm birth. Am J Obstet Gynecol. 2005;192(2):513-519.

40. Arteaga-Guerra JJ, Cerón-Souza V, Mafla AC. Dynamic among periodontal disease, stress, and adverse pregnancy outcomes. Rev Salud Pública. 2010;12(2):276-286.

41. Buduneli N, Baylas H, Buduneli E, Türkoğlu O, Köse T, Dahlen G. Periodontal infections and pre-term low birth weight: a case-control study. J Clin Periodontol. 2005;32(2):174-181.

42. Jacob PS, Nath S. Periodontitis among poor rural Indian mothers increases the risk of low birth weight babies: a hospital-based case control study. J Periodontal Implant Sci. 2014;44(2):85-93.

43. Pozo E, Mesa F, Ikram MH, et al. Preterm birth and/or low birth weight are associated with periodontal disease and the increased placental immunohistochemical expression of inflammatory markers. Histol Histopathol. 2016;31(2):231-237.

44. Muwazi L, Rwenyonyi CM, Nkamba M, et al. Periodontal conditions, low birth weight and preterm birth among postpartum mothers in two tertiary health facilities in Uganda. BMC Oral Health. 2014;14(1):42.

45. Chakki BA, Ealla KR, Hunsingi P, Kumar A, Manidanappanavar P. Influence of maternal periodontal disease as a risk factor for low birth weight infants in Indian population. J Contemp Dent Pract. 2012;13(5): 676-680. 
46. Dasanayake AP, Li Y, Wiener H, Ruby JD, Lee MJ. Salivary Actinomyces naeslundii genospecies 2 and Lactobacillus casei levels predict pregnancy outcomes. J Periodontol. 2005;76(2):171-177.

47. Marakoglu I, Gursoy UK, Marakoglu K, Cakmak H, Ataoglu T. Periodontitis as a risk factor for preterm low birth weight. Yonsei Med J. 2008;49(2):200-203.

48. Piscoya MD, Ximenes RA, Silva GM, Jamelli SR, Coutinho SB. Maternal periodontitis as a risk factor for prematurity. Pediatr Int. 2012; 54(1):68-75.

49. Soroye M, Ayanbadejo P, Savage K, Oluwole A. Association between periodontal disease and pregnancy outcomes. Odontostomatol Trop. 2015;38(152):5-16.

50. American College of Obstetricians and Gynecologists. Oral Health Care During Pregnancy and Through the Lifespan. Committee Opinion No 569. Obstet Gynecol. 2013;122(2):417-422.

51. Reza Karimi M, Hamissi JH, Naeini SR, Karimi M. The relationship between maternal periodontal status of and preterm and low birth weight infants in Iran: a case control study. Glob J Health Sci. 2015;8(5): 184-188.

52. Santa Cruz I, Herrera D, Martin C, Herrero A, Sanz M. Association between periodontal status and pre-term and/or low-birth weight in Spain: clinical and microbiological parameters. J Periodontal Res. 2013;48(4): 443-451.

53. Basha S, Shivalinga Swamy H, Noor Mohamed R. Maternal periodontitis as a possible risk factor for preterm birth and low birth weight-A Prospective Study. Oral Health Prev Dent. 2015;13(6):537-544.

54. Clothier B, Stringer M, Jeffcoat MK. Periodontal disease and pregnancy outcomes: exposure, risk and intervention. Best Pract Res Clin Obstet Gynaecol. 2007;21(3):451-466.

55. Alhaj AM, Radi EA, Adam I. Epidemiology of preterm birth in Omdurman maternity Hospital, Sudan. J Matern Fetal Neonatal Med. 2010;23(2):131-134.

56. Silk H, Ab D, Douglass JM, Silk L. DOUGLASS oral health during pregnancy. Am Fam Physician. 2008;77(8):1139-1144.

57. Baba S, Wikström AK, Stephansson O, Cnattingius S. Influence of smoking and snuff cessation on risk of preterm birth. Eur J Epidemiol. 2012;27(4):297-304.

58. Inamdar AS, Croucher RE, Chokhandre MK, Mashyakhy MH, Marinho VCC. Maternal smokeless tobacco use in pregnancy and adverse health outcomes in newborns: a systematic review. NICTOB. 2015;17(9):1058-1066.

59. Suliankatchi RA, Sinha DN. The human cost of tobacco chewing among pregnant women in India: a systematic review and meta-analysis. J Obstet Gynecol India. 2016;66(S1):161-166.

60. Aliyu M, Lynch O'Neil, Saidu R, Alio A, Marty P, Salihu H. Intrauterine exposure to tobacco and risk of medically indicated and spontaneous preterm birth. Am J Perinatol. 2010;27(05):405-410.

61. Shub A, Swain JR, Newnham JP. Periodontal disease and adverse pregnancy outcomes. J Matern Fetal Neonatal Med. 2006;19(9):521-528.

62. Ion R, Bernal AL. Smoking and preterm birth. Reprod Sci. 2015;22(8): 918-926.

63. Wagijo MA, Sheikh A, Duijts L, Been JV. Reducing tobacco smoking and smoke exposure to prevent preterm birth and its complications. Paediatr Respir Rev. 2017;22:3-10.

64. Jeffcoat MK, Geurs NC, Reddy MS, Cliver SP, Goldenberg RL, Hauth JC. Periodontal infection and preterm birth: results of a prospective study. $J$ Am Dent Assoc. 2001;132(7):875-880.

65. Offenbacher S, Lieff S, Boggess KA, et al. Maternal periodontitis and prematurity. Part I: Obstetric outcome of prematurity and growth restriction. Ann Periodontol. 2001;6(1):164-174.

66. Sharma R, Maimanuku LR, Morse Z, Pack AR. Preterm low birth weights associated with periodontal disease in the Fiji islands. Int Dent J. 2007;57(4):257-260.

67. Gazolla CM, Ribeiro A, Moysés MR, Oliveira LA, Pereira LJ, Sallum AW. Evaluation of the incidence of preterm low birth weight in patients undergoing periodontal therapy. J Periodontol. 2007;78(5):842-848.
68. Qualitative research review guidelines - RATS [webpage on the Internet]. BioMed Central Ltd; 2016. Available from: https://bmjopen.bmj.com/content/supp1/2012/01/12/bmjopen-2011-000138. DC1/BMJ_Open_IMG_Physician_Migration_RATS_Checklist.pdf. Accessed January 1, 2016.

69. Clark J. How to peer review a qualitative manuscript. Peer Review in Health Sciences. Second Godlee F, Jefferson T, editors. London: BMJ Books; 2003:219-235.

70. Morgan DL. Focus groups. Annu Rev Sociol. 1996;22(1):129-152.

71. Pope C, Mays N. Reaching the parts other methods cannot reach: an introduction to qualitative methods in health and health services research. BMJ. 1995;311(6996):42-45.

72. Braun V, Clarke V. Using thematic analysis in Psychology. Qual Res Psychol. 2006;3(2):77-101.

73. Braun V, Clarke V. What can "thematic analysis" offer health and wellbeing researchers? Int J Qual Stud Health Well-being. 2014;9(1):26152.

74. Chisenga JZ, Chalanda M, Ngwale M. Kangaroo mother care: a review of mothers' experiences at Bwaila hospital and Zomba central Hospital (Malawi). Midwifery. 2015;31(2):305-315.

75. Lydon M, Longwe M, Likomwa D, et al. Starting the conversation: community perspectives on preterm birth and kangaroo mother care in southern Malawi. J Glob Health. 2018;8(1):10703.

76. Lima G, Quintero-Romero S, Cattaneo A. Feasibility, acceptability and cost of kangaroo mother care in Recife, Brazil. Ann Trop Paediatr. 2000;20(1):22-26.

77. Kadam S, Binoy S, Kanbur W, Mondkar JA, Fernandez A. Feasibility of kangaroo mother care in Mumbai. Indian J Pediatr. 2005;72(1):35-38.

78. Parmar VR, Kumar A, Kaur R, et al. Experience with kangaroo mother care in a neonatal intensive care unit (NICU) in Chandigarh, India. Indian J Pediatr. 2009;76(1):25-28.

79. Gathwala G, Singh B, Singh J. Effect of kangaroo mother care on physical growth, breastfeeding and its acceptability. Trop Doct. 2010; 40(4):199-202.

80. Mazumder S, Upadhyay RP, Hill Z, et al. Kangaroo mother care: using formative research to design an acceptable community intervention. BMC Public Health. 2018;18(1):307.

81. Appareddy S, Pryor J, Bailey B. Inter-pregnancy interval and adverse outcomes: evidence for an additional risk in health disparate populations. J Matern Fetal Neonatal Med. 2016:1-5.

82. Shachar BZ, Mayo JA, Lyell DJ, et al. Interpregnancy interval after live birth or pregnancy termination and estimated risk of preterm birth: a retrospective cohort study. BJOG: Int J Obstet Gy. 2016;123(12): 2009-2017.

83. Koullali B, Kamphuis EI, Hof MH, et al. The effect of Interpregnancy interval on the recurrence rate of spontaneous preterm birth: a retrospective cohort study. Am J Perinatol. 2017;34(2):174-182.

84. Lengyel CS, Ehrlich S, Iams JD, Muglia LJ, Defranco EA. Effect of modifiable risk factors on preterm birth: a population Based-Cohort. Matern Child Health J. 2017;21(4):777-785.

85. Moore E, Blatt K, Chen A, van Hook J, Defranco EA. Relationship of trimester-specific smoking patterns and risk of preterm birth. Am J Obstet Gynecol. 2016;215(1):109.e1-6.

86. Wallace JL, Aland KL, Blatt K, Moore E, Defranco EA. Modifying the risk of recurrent preterm birth: influence of trimester-specific changes in smoking behaviors. Am J Obstet Gynecol. 2017;216(3):310.e1-8.

87. Zhang X, Devasia R, Czarnecki G, Frechette J, Russell S, Behringer B. Effects of incentive-based smoking cessation program for pregnant women on birth outcomes. Matern Child Health J. 2017;21(4):745-751.

88. Khan N, Jamal M. Maternal risk factors associated with low birth weight. J Coll Physicians Surg Pak. 2003;13(1):25-28.

89. Wu G, Imhoff-Kunsch B, Girard AW. Biological mechanisms for nutritional regulation of maternal health and fetal development. Paediatr Perinat Epidemiol. 2012;26(Suppl 1):4-26.

90. Gotsch F, Gotsch F, Romero R, et al. The preterm parturition syndrome and its implications for understanding the biology, risk assessment, diagnosis, treatment and prevention of preterm birth. J Matern Fetal Neonatal Med. 2009;22(Suppl 2):5-23. 
91. Romero R, Gomez R, Ghezzi F, et al. A fetal systemic inflammatory response is followed by the spontaneous onset of preterm parturition. Am J Obstet Gynecol. 1998;179(1):186-193.

92. Lee J, Romero R, Xu Y, et al. A signature of maternal anti-fetal rejection in spontaneous preterm birth: chronic chorioamnionitis, antihuman leukocyte antigen antibodies, and C4d. PLoS One. 2011;6(2): e16806.

93. Vaisbuch E, Romero R, Erez O, et al. Activation of the alternative pathway of complement is a feature of pre-term parturition but not of spontaneous labor at term. Am J Reprod Immunol. 2010;63(4): 318-330.

94. Blank V, Hirsch E, Challis JRG, Romero R, Lye SJ. Cytokine signaling, inflammation, innate immunity and preterm labour - a workshop report. Placenta. 2008;29(Suppl A):102-104.

95. Simhan HN, Macpherson T, Caritis SN, Krohn MA. Maternal and fetal Toll-like receptor 4 genotype and chorionic plate inflammatory lesions. Am J Obstet Gynecol. 2008;199(4):400.e1-4.

96. Simhan HN, Bodnar LM. Prepregnancy body mass index, vaginal inflammation, and the racial disparity in preterm birth. Am J Epidemiol. 2006;163(5):459-466.

97. Goepfert AR, Goldenberg RL, Andrews WW, et al. The preterm prediction study: association between cervical interleukin 6 concentration and spontaneous preterm birth. Am J Obstet Gynecol. 2001;184(3): 483-488.

98. Soto E, Romero R, Richani K, et al. Evidence for complement activation in the amniotic fluid of women with spontaneous preterm labor and intra-amniotic infection. J Matern Fetal Neonatal Med. 2009;22(11): 983-992.

99. Prince AL, Antony KM, Chu DM, Aagaard KM. The microbiome, parturition, and timing of birth: more questions than answers. J Reprod Immunol. 2014;104-105:12-19.

100. Ganu R, Ma J, Aagaard K. The role of microbial communities in parturition: is there evidence of association with preterm birth and perinatal morbidity and mortality? Am J Perinatol. 2013;30(08):613-624

101. Gómez LM, Sammel MD, Appleby DH, et al. Evidence of a geneenvironment interaction that predisposes to spontaneous preterm birth: a role for asymptomatic bacterial vaginosis and DNA variants in genes that control the inflammatory response. Am J Obstet Gynecol. 2010;202(4):386.e1-6.

102. Hecht JL, Allred EN, Kliman HJ, et al. Histological characteristics of singleton placentas delivered before the 28th week of gestation. Pathology. 2008;40(4):372-376.

103. Sorokin Y, Romero R, Mele L, et al. Maternal serum interleukin-6, C-reactive protein, and matrix metalloproteinase- 9 concentrations as risk factors for preterm birth $<32$ weeks and adverse neonatal outcomes. Am J Perinatol. 2010;27(8):631-640.

104. Romero R, Sibai B, Caritis S, et al. Antibiotic treatment of preterm labor with intact membranes: a multicenter, randomized, double-blinded, placebo-controlled trial. Am J Obstet Gynecol. 1993;169(4):764-774.

105. Romero R, Dey SK, Fisher SJ. Preterm labor: one syndrome, many causes. Science. 2014;345(6198):760-765.

106. Althabe F, Belizán JM, Em M, Mcclure EM. A population-based, multifaceted strategy to implement antenatal corticosteroid treatment versus standard care for the reduction of neonatal mortality due to preterm birth in low-income and middle-income countries: the act cluster-randomised trial. Lancet. 2014;6736(14):1-11.

107. Chung MY, Fang PC, Chung CH, Chen CC, Hwang KP, Chen FS. Comparison of neonatal outcome for inborn and outborn very lowbirthweight preterm infants. Pediatr Int. 2009;51(2):233-236.

108. Palmer KG, Kronsberg SS, Barton BA, Hobbs CA, Hall RW, Anand KJ. Effect of inborn versus outborn delivery on clinical outcomes in ventilated preterm neonates: secondary results from the NEOPAIN trial. J Perinatol. 2005;25(4):270-275.

109. Atnafu H, Belete Z, Kinfu H, Tadesse M, Amin M, Ballard KD. Can a community-based maternal care package in rural Ethiopia increase the use of health facilities for childbirth and reduce the stillbirth rate? Int $J$ Womens Health. 2016;8:421-428.
110. Hailu D, Berhe H. Determinants of institutional childbirth service utilisation among women of childbearing age in urban and rural areas of Tsegedie district, Ethiopia. Midwifery. 2014;30(11):1109-1117.

111. Kifle MM, Kesete HF, Gaim HT, Angosom GS, Araya MB. Health facility or home delivery? factors influencing the choice of delivery place among mothers living in rural communities of Eritrea. $J$ Health Popul Nutr. 2018;37(1):22.

112. Hagos S, Shaweno D, Assegid M, Mekonnen A, Afework MF, Ahmed S. Utilization of institutional delivery service at Wukro and Butajera districts in the Northern and South Central Ethiopia. BMC Pregnancy Childbirth. 2014;14:178.

113. Kitui J, Lewis S, Davey G. Factors influencing place of delivery for women in Kenya: an analysis of the Kenya demographic and Health survey, 2008/2009. BMC Pregnancy Childbirth. 2013;13:40.

114. Karanja S, Gichuki R, Igunza P, et al. Factors influencing deliveries at health facilities in a rural Maasai community in Magadi sub-County, Kenya. BMC Pregnancy Childbirth. 2018;18(1):5.

115. Anyait A, Mukanga D, Oundo GB, Nuwaha F. Predictors for health facility delivery in Busia district of Uganda: a cross sectional study. BMC Pregnancy Childbirth. 2012;12:132.

116. Kumbani LC, Chirwa E, Malata A, Odland JØ, Bjune G. Do Malawian women critically assess the quality of care? A qualitative study on women's perceptions of perinatal care at a district hospital in Malawi. Reprod Health. 2012;9(1):30.

117. Boutin A, Demers S, Roberge S, Roy-Morency A, Chandad F, Bujold E. Treatment of periodontal disease and prevention of preterm birth: systematic review and meta-analysis. Am J Perinatol. 2013;30(7): 537-544.

118. Shah M, Muley A, Muley P. Effect of nonsurgical periodontal therapy during gestation period on adverse pregnancy outcome: a systematic review. J Matern Fetal Neonatal Med. 2013;26(17):1691-1695.

119. López NJ, Da Silva I, Ipinza J, Gutiérrez J. Periodontal therapy reduces the rate of preterm low birth weight in women with pregnancy-associated gingivitis. J Periodontol. 2005;76(11 Suppl): 2144-2153.

120. Gomes-Filho IS, Cruz SS, Costa MC, et al. Periodontal therapy and low birth weight: preliminary results from an alternative methodologic strategy. J Periodontol. 2010;81(12):1725-1733.

121. Khairnar MS, Pawar BR, Marawar PP, Khairnar DM. Estimation of changes in C-reactive protein level and pregnancy outcome after nonsurgical supportive periodontal therapy in women affected with periodontitis in a rural set up of India. Contemp Clin Dent. 2015; 6(Suppl 1):S5-S11.

122. Sant'ana AC, Campos MR, Passanezi SC, Rezende ML, Greghi SL, Passanezi E. Periodontal treatment during pregnancy decreases the rate of adverse pregnancy outcome: a controlled clinical trial. $J \mathrm{Appl}$ Oral Sci. 2011;19(2):130-136.

123. George A, Shamim S, Johnson M, et al. Periodontal treatment during pregnancy and birth outcomes: a meta-analysis of randomised trials. Int J Evid Based Healthc. 2011;9(2):122-147.

124. Kim AJ, Lo AJ, Pullin DA, Thornton-Johnson DS, Karimbux NY. Scaling and root planing treatment for periodontitis to reduce preterm birth and low birth weight: a systematic review and metaanalysis of randomized controlled trials. J Periodontol. 2012;83(12): 1508-1519.

125. Polyzos NP, Polyzos IP, Zavos A, et al. Obstetric outcomes after treatment of periodontal disease during pregnancy: systematic review and meta-analysis. BMJ. 2010;341:c7017.

126. Fogacci MF, Vettore MV, Leão AT. The effect of periodontal therapy on preterm low birth weight: a meta-analysis. Obstet Gynecol. 2011; 117(1):153-165.

127. Offenbacher S, Beck JD, Jared HL, et al. Effects of periodontal therapy on rate of preterm delivery: a randomized controlled trial. Obstet Gynecol. 2009;114(3):551-559.

128. Michalowicz BS, Hodges JS, Diangelis AJ, et al. Treatment of periodontal disease and the risk of preterm birth. $N$ Engl J Med. 2006; 355(18):1885-1894. 
129. Newnham JP, Newnham IA, Ball CM, et al. Treatment of periodontal disease during pregnancy: a randomized controlled trial. Obstet Gynecol. 2009;114(6):1239-1248.

130. Macones GA, Parry S, Nelson DB, et al. Treatment of localized periodontal disease in pregnancy does not reduce the occurrence of preterm birth: results from the periodontal infections and Prematurity Study (PIPs). Am J Obstet Gynecol. 2010;202(2):147.e1-8.

131. Schwendicke F, Karimbux N, Allareddy V, Gluud C. Periodontal treatment for preventing adverse pregnancy outcomes: a meta- and trial sequential analysis. PLoS One. 2015;10(6):e0129060.

132. Chambrone L, Pannuti CM, Guglielmetti MR, Chambrone LA. Evidence grade associating periodontitis with preterm birth and/or low birth weight: II: a systematic review of randomized trials evaluating the effects of periodontal treatment. J Clin Periodontol. 2011;38(10): 902-914.

133. Pirie $M$, Linden $G$, Irwin $C$. Intrapregnancy and non surgical periodontal treatment and pregnancy outcomes. J Periodontol. 2013;84(10): 1391-1400.

134. Jeffcoat M, Parry S, Sammel M, Clothier B, Catlin A, Macones G. Periodontal infection and preterm birth: successful periodontal therapy reduces the risk of preterm birth. BJOG. 2011;118(2):250-256.

135. World Health Organization [homepage on the Internet]. Oral health services. Available from: http://www.who.int/oral_health/action/ services/en/. Published 2016. Accessed December 8, 2016.

136. Pack AR. Dental services and needs in developing countries. Int Dent J. 1998;48(3 Suppl 1):239-247.

137. Saparamadu KD. Prevention of oral diseases in developing countries. Int Dent J. 1984;34(3):166-169.

138. Trahan L. Xylitol: a review of its action on mutans streptococci and dental plaque - its clinical significance. Int Dent J. 1995;45(1 Suppl 1): 77-92.

139. Keukenmeester RS, Slot DE, Rosema NAM, van Loveren C, van der Weijden GA. Effects of sugar-free chewing gum sweetened with xylitol or maltitol on the development of gingivitis and plaque: a randomized clinical trial. Int J Dent Hyg. 2014;12(4):238-244.

140. Shyama M, Honkala E, Honkala S, Al-Mutawa SA. Effect of xylitol candies on plaque and gingival indices in physically disabled school pupils. J Clin Dent. 2006;17(1):17-21.

141. Simons D, Beighton D, Kidd EA, Collier FI. The effect of xylitol and chlorhexidine acetate/xylitol chewing gums on plaque accumulation and gingival inflammation. J Clin Periodontol. 1999;26(6):388-391.

142. Steinberg LM, Odusola F, Mandel ID. Remineralizing potential, antiplaque and antigingivitis effects of xylitol and sorbitol sweetened chewing gum. Clin Prev Dent. 1992;14(5):31-34.
143. Mäkinen KK, Pemberton D, Mäkinen PL, et al. Polyol-combinant saliva stimulants and oral health in Veterans Affairs patients-an exploratory study. Spec Care Dentist. 1996;16(3):104-115.

144. Kandelman D, Gagnon G. Clinical results after 12 months from a study of the incidence and progression of dental caries in relation to consumption of chewing-gum containing xylitol in school preventive programs. J Dent Res. 1987;66(8):1407-1411.

145. Isokangas P, Tiekso J, Alanen P, Mäkinen KK. Long-term effect of xylitol chewing gum on dental caries. Community Dent Oral Epidemiol. 1989;17(4):200-203.

146. Mäkinen KK, Bennett CA, Hujoel PP, et al. Xylitol chewing gums and caries rates: a 40-month cohort study. J Dent Res. 1995;74(12): 1904-1913.

147. Mäkinen KK, Mäkinen PL, Pape HR, et al. Stabilisation of rampant caries: polyol gums and arrest of dentine caries in two long-term cohort studies in young subjects. Int Dent J. 1995;45(1 Suppl 1):93-107.

148. Makinen KK, Hujoel PP, Bennett CA, et al. A descriptive report of the effects of a 16-month xylitol chewing-gum programme subsequent to a 40-month sucrose gum programme. Caries Res. 1998;32(2):107-112.

149. Makinen KK, Chiego DJJ, Allen P, et al. Physical, chemical, and histologic changes in dentin caries lesions of primary teeth induced by regular use of polyol chewing gums. Acta Odontol Scand. 1998;56(3): $148-156$.

150. Makinen KK, Makinen PL, Pape HRJ, et al. Conclusion and review of the Michigan xylitol programme (1986-1995) for the prevention of dental caries. Int Dent J. 1996;46(1):22-34.

151. Mäkinen KK, Chen CY, Mäkinen PL, et al. Properties of whole saliva and dental plaque in relation to 40-month consumption of chewing gums containing xylitol, sorbitol of sucrose. Caries Res. 1996;30(3): 180-188.

152. Söderling E, Mäkinen KK, Chen CY, Pape HR, Loesche W, Mäkinen PL. Effect of sorbitol, xylitol, and xylitol/sorbitol chewing gums on dental plaque. Caries Res. 1989;23(5):378-384.

153. Lehmann U, Sanders D. Department of Human Resources for Health. Community Health Workers: What Do We Know about Them? The State of the Evidence on Programmes, Activities, Costs, and Impact on Health Outcomes of Using Community Health Workers. Evidence and Information for Policy. Geneva, Switzerland; 2007. Available from: https://www.who.int/hrh/documents/community_health_workers.pdf. Accessed November 12, 2018.

154. Makwero MT. Delivery of primary health care in Malawi. Afr J Prim Health Care Fam Med. 2018;10(1):1-3. 


\section{Supplementary material}

Table SI Lead-in prompts for providers only

\begin{tabular}{|l|l|}
\hline Topic & \multicolumn{2}{l|}{ Question } \\
\hline Additional education requests \\
\hline "Open Day" & • What would you like to know more about during an "Open Day" \\
\hline Preterm birth & • Are there areas of preterm birth or being born too soon/too small that you wish you knew more about? \\
\hline Knowledge gaps & • Are there gaps in your knowledge you would like to be filled? \\
\hline Obstetrical or clinical skills & • Are there obstetrical skills or practicum that you wish you were more comfortable with? \\
\hline
\end{tabular}

International Journal of Women's Health

\section{Publish your work in this journal}

The International Journal of Women's Health is an international, peerreviewed open-access journal publishing original research, reports, editorials, reviews and commentaries on all aspects of women's healthcare including gynecology, obstetrics, and breast cancer. The manuscript management system is completely online and includes

Submit your manuscript here: http://www.dovepress.com/international-journal-of-womens-health-journal
Dovepress

a very quick and fair peer-review system, which is all easy to use. Visit http://www.dovepress.com/testimonials.php to read real quotes from published authors. 